\title{
EXPERIMENTAL ECOLOGICAL RESEARCH ON THE RELATIONSHIPS OF PATHOGENIC MICROORGANISMS WITH ALGAE
}

\author{
O. M. Zhukorskyi ${ }^{1}$, N. P. Tkachuk ${ }^{2}$, O. V. Hulai ${ }^{3}$, V. V. Hulai ${ }^{3}$ \\ ${ }^{1}$ National Academy of Agrarian Sciences of Ukraine, \\ 9, Omelianovycha-Pavlenka Str, Kyiv, Ukraine 01010 \\ ${ }^{2}$ Institute of Agroecology and Environmental Economics, NAAS of Ukraine, \\ 12, Metrologichna Str., Kyiv, Ukraine, 03143 \\ ${ }^{3}$ Volodymyr Vynnychenko Central Ukrainian State Pedagogical University \\ 1, Shevchenko Str, Kropyvnytskyi, Ukraine, 25006
}

E-mail:o_zhukorskiy@ukr.net,ol.gulay42@gmail.com*,tkachuknatalja777@gmail.com,vit.gulay@gmail.com

Received September 17, 2019 / Received October 27, 2019 / Accepted November 19, 2019

\begin{abstract}
Aim. The ecological relationships between Leptospira interrogans spirochetes and Chlamydomonas proteus algae and the response explicitness of individual serological types of leptospires to the allelopathic effect of algae were to be investigated during the experiment. Methods. C. proteus algae monocultures were cultivated on the Fitzgerald's medium in the Zehnder and Gorham's modification. Sterile filtrates of their cultures were diluted with the nutrient medium in the ratio of $1: 10,1: 100,1: 1,000,1: 10,000$. Leptospires were cultivated on the Terskih and Korthof's medium with the addition of $10 \%$ inactivated sheep blood serum. The test samples contained diluted culture filtrates of algae and leptospires. The control samples were the environment for algae and leptospires cultivation. Results. In the samples with the $1: 10-1: 100$ dilution of algae filtrates, the content of leptospires in the test samples was significantly lower than in the control samples, indicating their moderate and weak inhibition. There were no statistically significant differences between spirochete culture densities in the test and control samples with the dilutions of $1: 1,000-1: 10,000$ algae filtrates. Conclusions. In the experiment, a topical type of ecological interspecies relationships is formed between L. interrogans and green species of $C$. proteus algae, which is realized through the release of biologically active substances into the habitat by $C$. proteus. According to the increasing sensitivity to the allelopathic effect of $C$. proteus, serological types of leptospires formed a row: Tarassovi, Icterohaemorrhagiae, Pomona, Grippotyphosa, Australis, Sejroe, Canicola, Hebdomadis.
\end{abstract}

Keywords: Leptospira interrogans, Chlamydomonas proteus, ecological relationships.

DOI:

\section{INTRODUCTION}

One of urgent and relevant challenges, facing humanity, is overcoming the consequences of planet climate changes. At present there are evident changes in the seasonal rainfall distribution in Ukraine's territory, there are more frequent temperature anomalies, experts forecast a rise in the level of the Sea of Azov and the Black Sea, desertification of southern and south-eastern regions of the country. There is also actual threat of considerable decrease in water resources and deteriora-

(C) O. M. ZHUKORSKYI, N. P. TKACHUK, O. V. HULAI, V. V. HULAI, 2019 tion of water quality. Due to these conditions, the issues of ensuring the purity of water sources and their safety for economic use become especially relevant.

Water is known to be one of the main paths of dissemination for many dangerous infectious and invasive diseases of humans and animals. A special place in this group of pathogenic microorganisms is taken by Leptospira interrogans spirochetes (Stimson 1907) Wenyon (1926). A wide range of hosts [1-6] and considerable ecological flexibility conditions pervasive dissemination of these pathogenic spirochetes. The cases of leptospirosis - a disease, caused by L. interrogans, are 
currently registered in many countries on all the continents, except for Antarctica [7-16].

The capability of pathogenic leptospires to exist in fresh water for a long time, forming natural sources of infection, makes these microorganisms extremely dangerous, especially in conditions of deficient water resources.

At present there are no effective mechanisms of recovering the territory from L. interrogans, except meliorative draining measures. However, such radical actions are not always reasonable both from ecological and economic standpoint. The biological method of combating pathogenic microorganisms in environmental objects opens new perspectives in this direction. However, its elaboration and application require the clarification of many issues, related to the existence of L. interrogans in different types of freshwater sources and the place of these microorganisms in a complicated network of biotic relationships between hydrobionts.

A considerable part of primary biological products in freshwater bodies is created by different species of algae. They are also one of the main sources of biologically active substances (BAS) for hydrobiocenoses, ensuring complicated allelopathic interactions between higher plants, algae and bacterial microflora.

Water bodies are an extremely complicated and dynamic environment for L. interrogans [15] which creates considerable methodological difficulties in planning, conducting experiments, and interpreting the obtained results in situ. The aforementioned and insufficient scientific data create conditions, due to which the study of ecological relationships between pathogenic microorganisms (L. interrogans) and freshwater algae should be conducted in in vitro experiments under controlled laboratory conditions.

The main aim of this study was to investigate the specificities of ecological relationships between patho- genic leptospires and algae - Chlamydomonas proteus Pringsheim 1930, and to compare the response of different serological types of $L$. interrogans to the effect of BAS, produced by this species of algae. Hopefully, the obtained data will facilitate more complete investigation on the specificities of biotic relationships of pathogenic leptospires in natural water bodies and provide sufficient data for further elaboration of efficient methods to decrease the potential of natural leptospirosis sources.

\section{MATERIALS AND METHODS}

Unialgal monocultures of green algae, C. proteus, were cultivated in Erlenmeyer flasks of $250 \mathrm{cc}$ on the Fitzgerald's medium in the Zehnder and Gorham's modification [18] at $22-25^{\circ} \mathrm{C}$ and 12 -hour-long photoperiod of artificial illumination with $25 \mathrm{klx}$ fluorescent lamps.

The Terskih and Korthof's medium, containing $10 \%$ inactivated sheep blood serum, was used to cultivate leptospires.

The cultures of spirochetes of 7-14 days with the accumulation of 50-100 leptospires per vision field, with characteristic morphology, active mobility and no signs of autoagglutination were used in the experiment. The experiments were conducted with cultures of the following strains of leptospires (Table 1), which are most widespread in Ukraine's territory, and used as antigens during laboratory diagnostics of leptospirosis in the serological reaction of microagglutination and lysis.

Culture solutions of algae were passed through sterile cellulose filters with pore diameter of $0.2 \mu \mathrm{m}$ (Sartorius, Germany). This method of sample preparation allowed removing the symbiotic microflora, notable for C. proteus cultures, and preventing the destruction of biologically active substances (BAS), released by algae.

The experiment, studying the allelopathic effect of green algae on pathogenic leptospires, simulated the

Table 1. L. interrogans spirochete strains, used in the study

\begin{tabular}{|c|c|c|c|}
\hline Serological group & Serological variant & Strain & Legend \\
\hline Australis & bratislava & Yez bratislava & Australis \\
\hline Canicola & canicola & Hond Utrecht IV & Canicola \\
\hline Grippotyphosa & grippotyphosa & Moskva V & Grippotyphosa \\
\hline Hebdomadis & kabura & Kabura & Hebdomadis \\
\hline Icterohaemorrhagiae & copenhageni & M 20 & Icterohaemorrhagiae \\
\hline Pomona & pomona & Pomona & Pomona \\
\hline Sejroe & pollonica & 493 Poland & Sejroe \\
\hline Tarassovi & tarassovi & Perepelicyn & Tarassovi \\
\hline
\end{tabular}


conditions of freshwater bodies on the territory of leptospirosis sources. In particular, the gradient of BAS concentration, released by algae in natural conditions, was presented in experimental samples by the following dilutions of $C$. proteus filtrates $-1: 10,1: 100$, $1: 1,000$, and $1: 10,000$. Control samples contained sterile culture Fitzgerald's medium in the Zehnder and Gorham's modification.

The samples were introduced the same volume of pathogenic leptospire cultures, here the inoculates of each serological type were taken from one volume. It ensured the same density of leptospires in the experiment and control at the beginning of the experiment. The study was conducted in five repeats. After $24 \mathrm{~h}$ since the beginning of the experiment, the content of spirochetes was determined in the experimental and control samples, using direct calculation in $40 \mu \mathrm{m}$ chambers.

The character and explicitness of the effect of green algae, $C$. proteus, secretions on pathogenic leptospires was evaluated, comparing the content of spirochetes in the experimental and control samples, here the density of cultures in the control was accepted as $100 \%$ [19].

\section{RESEARCH RESULTS}

Explicit inhibition of experimental cultures of $L$. interrogans was observed in the experimental samples, containing cultural filtrates of $C$. proteus in 1:10 dilution (Table 2). For instance, after $24 \mathrm{~h}$ since the be- ginning of the experiment the content of leptospires in the experimental samples was as follows ( $\%$ from the control): Tarassovi $-78.0 \%$, Pomona - $70.4 \%$, Canicola- $61.0 \%$, Hebdomadis - 57.8 \%, Sejroe - $63.8 \%$, Icterohaemorrhagiae - $71.0 \%$, Grippotyphosa $66.4 \%$, Australis $-64.6 \%$.

Using the criteria of estimating the effect of ecological factors on populations (cultures) of microorganisms [19], we would like to note that according to the experiment results, the leptospire cultures of serological types Pomona, Canicola, Hebdomadis, Sejroe, Icterohaemorrhagiae, Grippotyphosa, Australis were exposed to moderate inhibition due to the allelopathic effect of $C$. proteus. The leptospire cultures of serological type Tarassovi had weak inhibition. According to the increasing sensitivity to the allelopathic effect of $C$. proteus, serological types of leptospires formed the following row: Tarassovi-22.0\% (an index of the effect of ecological factor (A), Icterohaemorrhagiae 29.0 \%, Pomona - 29.6 \%, Grippotyphosa - 33.6 \%, Australis-35.4\%, Sejroe-36.2\%, Canicola-39.0\%, Hebdomadis $-42.2 \%$.

Lower density of $L$. interrogans, compared to the control, was noted in another group of experimental samples, containing cultural filtrates of $C$. proteus in 1 : 100 dilution. For instance, it was determined that the density of leptospire cells in the tests, taken from the experimental samples, was as follows ( $\%$ from the control): Tarassovi - $89.4 \%$, Pomona - $86.2 \%$, Canico-

Table 2. The density of $L$. interrogans cultures in the experiment on the effect of cultural filtrates of $C$. proteus in $1: 10$ dilution

\begin{tabular}{|c|c|c|c|c|c|c|c|c|c|c|c|c|c|c|c|}
\hline \multicolumn{16}{|c|}{ Density of cultures of different serological variants, $\times 10^{6} / \mathrm{cc}$} \\
\hline \multicolumn{2}{|c|}{ Sejroe } & \multicolumn{2}{|c|}{ Hebdomadis } & \multicolumn{2}{|c|}{ Tarassovi } & \multicolumn{2}{|c|}{ Pomona } & \multicolumn{2}{|c|}{ Grippotyphosa } & \multicolumn{2}{|c|}{ Canicola } & \multicolumn{2}{|c|}{$\begin{array}{l}\text { Icterohae- } \\
\text { morrhagiae }\end{array}$} & \multicolumn{2}{|c|}{ Australis } \\
\hline $\mathrm{E}^{*}$ & $\mathrm{C}$ & $\mathrm{E}$ & $\mathrm{C}$ & $\mathrm{E}$ & $\mathrm{C}$ & $\mathrm{E}$ & $\mathrm{C}$ & $\mathrm{E}$ & $\mathrm{C}$ & $\mathrm{E}$ & $\mathrm{C}$ & $\mathrm{E}$ & $\mathrm{C}$ & $\mathrm{E}$ & $\mathrm{C}$ \\
\hline 11.50 & 16.30 & 6.70 & 10.90 & 6.70 & 8.40 & 5.70 & 7.10 & 13.50 & 21.40 & 7.60 & 13.30 & 4.80 & 6.50 & 6.50 & 10.50 \\
\hline 10.30 & 18.20 & 7.20 & 12.40 & 6.10 & 8.20 & 4.90 & 7.60 & 11.80 & 20.90 & 8.00 & 12.10 & 5.00 & 6.70 & 7.00 & 9.40 \\
\hline 9.80 & 17.50 & 6.90 & 11.70 & 6.50 & 7.50 & 5.30 & 8.00 & 13.20 & 19.50 & 8.20 & 12.50 & 4.70 & 7.30 & 6.80 & 10.70 \\
\hline 11.10 & 15.10 & 7.30 & 13.30 & 5.90 & 8.60 & 5.60 & 7.80 & 14.40 & 18.70 & 8.50 & 14.30 & 4.90 & 6.90 & 6.40 & 11.20 \\
\hline 10.80 & 16.70 & 6.80 & 12.10 & 6.30 & 7.70 & 5.10 & 7.30 & 12.70 & 18.30 & 7.90 & 13.70 & 5.10 & 7.10 & 6.70 & 9.90 \\
\hline \multicolumn{16}{|c|}{$M$} \\
\hline 10.70 & 16.76 & 6.98 & 12.08 & 6.30 & 8.08 & 5.32 & 7.56 & 13.12 & 19.76 & 8.04 & 13.18 & 4.90 & 6.90 & 6.68 & 10.34 \\
\hline \multicolumn{16}{|c|}{$t$} \\
\hline \multicolumn{2}{|c|}{9.98} & \multicolumn{2}{|c|}{12.38} & \multicolumn{2}{|c|}{7.07} & \multicolumn{2}{|c|}{10.12} & \multicolumn{2}{|c|}{8.95} & \multicolumn{2}{|c|}{12.08} & \multicolumn{2}{|c|}{12.65} & \multicolumn{2}{|c|}{11.04} \\
\hline
\end{tabular}

*Note. Hereinafter: $\mathrm{E}$ - experiment; $\mathrm{C}$ - control; $\mathrm{M}$ - mean arithmetic; $\mathrm{t}$ - Student's coefficient; $\mathrm{t}$ - critical value of parameter $\mathrm{t} ; \mathrm{P}$ - probability rate. 
la-78.5\%, Hebdomadis - 82.8\%, Sejroe - $85.3 \%$, Icterohaemorrhagiae - $83.4 \%$, Grippotyphosa-80.3\%, Australis - $76.8 \%$ (Table 3).

The analysis of the obtained data demonstrated that the content of cultural filtrates of $C$. proteus in the medium in $1: 100$ dilution caused weak inhibition of leptospires of serological types - Hebdomadis, Icterohaemorrhagiae, Pomona, Grippotyphosa, Canicola, Sejroe, Australis. Here the index of the effect of ecological factor was as follows: Pomona $-13.8 \%$, Sejroe - $14.7 \%$, Icterohaemorrhagiae - $16.5 \%$, Hebdomadis - $17.2 \%$, Grippotyphosa - $19.7 \%$, Canicola $-21.5 \%$, Australis $-23.2 \%$. At the same time, no explicit effect of experimental algae secretions was determined in the samples with leptospire cultures of serological type Tarassovi.

In the subsequent experiments with an even higher dilution index for cultural filtrates of $C$. proteus $1: 1,000$, the difference between the density of leptospire cultures in the experiment and control was as follows: Tarassovi - $92.3 \%$, Pomona - $88.9 \%$, Canicola - $93.8 \%$, Hebdomadis - 89.4 \%, Sejroe - $90.6 \%$, Icterohaemorrhagiae - $89.3 \%$, Grippotyphosa-91.8\%, Australis $-87.8 \%$ (Table 4).

The results demonstrated that according to the accepted criterion of estimating the effect of ecological

Table 3. The density of $L$. interrogans cultures in the experiment on the effect of cultural filtrates of C. proteus in $1: 100$ dilution

Density of cultures of different serological variants, $\times 10^{6} / \mathrm{cc}$

\begin{tabular}{|c|c|c|c|c|c|c|c|c|c|c|c|c|c|c|c|}
\hline \multicolumn{2}{|c|}{ Sejroe } & \multicolumn{2}{|c|}{ Hebdomadis } & \multicolumn{2}{|c|}{ Tarassovi } & \multicolumn{2}{|c|}{ Pomona } & \multicolumn{2}{|c|}{ Grippotyphosa } & \multicolumn{2}{|c|}{ Canicola } & \multicolumn{2}{|c|}{$\begin{array}{l}\text { Icterohae- } \\
\text { morrhagiae }\end{array}$} & \multicolumn{2}{|c|}{ Australis } \\
\hline E & $\mathrm{C}$ & $\mathrm{E}$ & $\mathrm{C}$ & $\mathrm{E}$ & $\mathrm{C}$ & $\mathrm{E}$ & $\mathrm{C}$ & $\mathrm{E}$ & $\mathrm{C}$ & E & $\mathrm{C}$ & $\mathrm{E}$ & $\mathrm{C}$ & E & $\mathrm{C}$ \\
\hline 15.20 & 16.30 & 9.60 & 10.90 & 7.00 & 8.40 & 6.70 & 7.10 & 14.20 & 21.40 & 10.50 & 13.30 & 5.60 & 6.50 & 7.70 & 10.50 \\
\hline 15.50 & 18.20 & 10.70 & 12.40 & 7.40 & 8.20 & 6.60 & 7.60 & 17.40 & 20.90 & 9.90 & 12.10 & 5.50 & 6.70 & 8.30 & 9.40 \\
\hline 13.30 & 17.50 & 9.30 & 11.70 & 7.70 & 7.50 & 6.90 & 8.00 & 15.70 & 19.50 & 11.10 & 12.50 & 5.90 & 7.30 & 7.90 & 10.70 \\
\hline 14.60 & 15.10 & 9.90 & 13.30 & 7.20 & 8.60 & 6.00 & 7.80 & 16.10 & 18.70 & 10.70 & 14.30 & 6.10 & 6.90 & 7.60 & 11.20 \\
\hline 12.90 & 16.70 & 10.50 & 12.10 & 6.80 & 7.70 & 6.40 & 7.30 & 15.90 & 18.30 & 9.50 & 13.70 & 5.70 & 7.10 & 8.20 & 9.90 \\
\hline \multicolumn{16}{|c|}{$M *$} \\
\hline 14.30 & 16.76 & 10.00 & 12.08 & 7.22 & 8.08 & 6.52 & 7.56 & 15.86 & 19.76 & 10.34 & 13.18 & 5.76 & 6.90 & 7.94 & 10.34 \\
\hline \multicolumn{16}{|c|}{$t$} \\
\hline \multicolumn{2}{|c|}{3.33} & \multicolumn{2}{|c|}{4.37} & \multicolumn{2}{|c|}{3.30} & \multicolumn{2}{|c|}{4.65} & \multicolumn{2}{|c|}{4.93} & \multicolumn{2}{|c|}{5.80} & \multicolumn{2}{|c|}{6.41} & \multicolumn{2}{|c|}{7.01} \\
\hline \multicolumn{16}{|c|}{$=3.36 ; \mathrm{P}=0.01$} \\
\hline
\end{tabular}

Table 4. The density of $L$. interrogans cultures in the experiment on the effect of cultural filtrates of $C$. proteus in $1: 1,000$ dilution Density of cultures of different serological variants, $\times 10^{6} / \mathrm{cc}$

\begin{tabular}{|c|c|c|c|c|c|c|c|c|c|c|c|c|c|c|c|}
\hline \multicolumn{2}{|c|}{ Sejroe } & \multicolumn{2}{|c|}{ Hebdomadis } & \multicolumn{2}{|c|}{ Tarassovi } & \multicolumn{2}{|c|}{ Pomona } & \multicolumn{2}{|c|}{ Grippotyphosa } & \multicolumn{2}{|c|}{ Canicola } & \multicolumn{2}{|c|}{$\begin{array}{l}\text { Icterohae- } \\
\text { morrhagiae }\end{array}$} & \multicolumn{2}{|c|}{ Australis } \\
\hline E & $\mathrm{C}$ & $\mathrm{E}$ & $\mathrm{C}$ & $\mathrm{E}$ & $\mathrm{C}$ & E & $\mathrm{C}$ & E & $\mathrm{C}$ & E & $\mathrm{C}$ & E & $\mathrm{C}$ & E & $\mathrm{C}$ \\
\hline 13.70 & 16.30 & 11.30 & 10.90 & 7.90 & 8.40 & 7.20 & 7.10 & 18.30 & 21.40 & 11.70 & 13.30 & 6.20 & 6.50 & 9.20 & 10.50 \\
\hline 15.90 & 18.20 & 9.90 & 12.40 & 7.60 & 8.20 & 6.90 & 7.60 & 17.70 & 20.90 & 12.30 & 12.10 & 6.10 & 6.70 & 9.70 & 9.40 \\
\hline 16.60 & 17.50 & 10.50 & 11.70 & 6.90 & 7.50 & 6.50 & 8.00 & 16.20 & 19.50 & 11.90 & 12.50 & 6.40 & 7.30 & 8.80 & 10.70 \\
\hline 15.50 & 15.10 & 11.60 & 13.30 & 7.40 & 8.60 & 6.30 & 7.80 & 18.50 & 18.70 & 12.50 & 14.30 & 6.20 & 6.90 & 8.40 & 11.20 \\
\hline 14.20 & 16.70 & 10.70 & 12.10 & 7.50 & 7.70 & 6.70 & 7.30 & 20.00 & 18.30 & 13.40 & 13.70 & 5.90 & 7.10 & 9.30 & 9.90 \\
\hline \multicolumn{16}{|c|}{$M *$} \\
\hline 15.18 & 16.76 & 10.80 & 12.08 & 7.46 & 8.08 & 6.72 & 7.56 & 18.14 & 19.76 & 12.36 & 13.18 & 6.16 & 6.90 & 9.08 & 10.34 \\
\hline \multicolumn{16}{|c|}{$t$} \\
\hline \multicolumn{2}{|c|}{2.09} & \multicolumn{2}{|c|}{2.58} & \multicolumn{2}{|c|}{2.34} & \multicolumn{2}{|c|}{3.72} & \multicolumn{2}{|c|}{1.88} & \multicolumn{2}{|c|}{1.65} & \multicolumn{2}{|c|}{4.54} & \multicolumn{2}{|c|}{3.28} \\
\hline
\end{tabular}


Table 5. The density of $L$. interrogans cultures in the experiment on the effect of cultural filtrates of $C$. proteus in $1: 10,000$ dilution

\begin{tabular}{|c|c|c|c|c|c|c|c|c|c|c|c|c|c|c|c|}
\hline \multicolumn{16}{|c|}{ Density of cultures of different serological variants, $\times 10^{6} / \mathrm{cc}$} \\
\hline \multicolumn{2}{|c|}{ Sejroe } & \multicolumn{2}{|c|}{ Hebdomadis } & \multicolumn{2}{|c|}{ Tarassovi } & \multicolumn{2}{|c|}{ Pomona } & \multicolumn{2}{|c|}{ Grippotyphosa } & \multicolumn{2}{|c|}{ Canicola } & \multicolumn{2}{|c|}{$\begin{array}{l}\text { Icterohae- } \\
\text { morrhagiae }\end{array}$} & \multicolumn{2}{|c|}{ Australis } \\
\hline $\mathrm{E}$ & $\mathrm{C}$ & $\mathrm{E}$ & $\mathrm{C}$ & $\mathrm{E}$ & $\mathrm{C}$ & $\mathrm{E}$ & $\mathrm{C}$ & $\mathrm{E}$ & $\mathrm{C}$ & $\mathrm{E}$ & $\mathrm{C}$ & $\mathrm{E}$ & $\mathrm{C}$ & $\mathrm{E}$ & $\mathrm{C}$ \\
\hline 17.20 & 16.30 & 12.50 & 10.90 & 8.30 & 8.40 & 7.50 & 7.10 & 22.20 & 21.40 & 14.90 & 13.30 & 7.30 & 6.50 & 9.90 & 10.50 \\
\hline 15.70 & 18.20 & 11.30 & 12.40 & 7.50 & 8.20 & 6.70 & 7.60 & 22.50 & 20.90 & 15.50 & 12.10 & 6.80 & 6.70 & 9.30 & 9.40 \\
\hline 16.90 & 17.50 & 10.20 & 11.70 & 7.70 & 7.50 & 7.00 & 8.00 & 19.80 & 19.50 & 14.80 & 12.50 & 7.10 & 7.30 & 9.50 & 10.70 \\
\hline 14.40 & 15.10 & 11.20 & 13.30 & 8.00 & 8.60 & 7.80 & 7.80 & 21.20 & 18.70 & 12.80 & 14.30 & 6.70 & 6.90 & 10.10 & 11.20 \\
\hline 15.30 & 16.70 & 11.40 & 12.10 & 7.40 & 7.70 & 7.10 & 7.30 & 18.60 & 18.30 & 13.10 & 13.70 & 7.00 & 7.10 & 10.60 & 9.90 \\
\hline \multicolumn{16}{|c|}{$M^{*}$} \\
\hline 15.90 & 16.76 & 11.32 & 12.08 & 7.78 & 8.08 & 7.22 & 7.56 & 20.86 & 19.76 & 14.22 & 13.18 & 6.98 & 6.90 & 9.88 & 10.34 \\
\hline \multicolumn{16}{|c|}{ 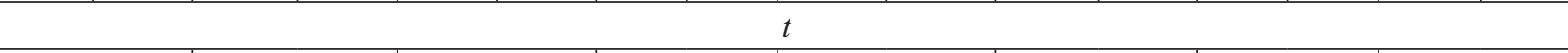 } \\
\hline \multicolumn{2}{|c|}{1.16} & \multicolumn{2}{|c|}{1.41} & \multicolumn{2}{|c|}{1.13} & \multicolumn{2}{|c|}{1.34} & \multicolumn{2}{|c|}{0.74} & \multicolumn{2}{|c|}{1.56} & \multicolumn{2}{|c|}{0.45} & \multicolumn{2}{|c|}{0.31} \\
\hline \multicolumn{16}{|c|}{$\mathrm{t}_{\mathrm{cr}}=3.36 ; \mathrm{P}=0.01$} \\
\hline
\end{tabular}

factors, the secretions of $C$. proteus in $1: 1,000$ dilution did not have explicit effect on leptospire cultures of the following serological types: Hebdomadis, Icterohaemorrhagiae, Pomona, Grippotyphosa, Canicola, Sejroe, Tarassovi. Only the samples, containing leptospire cultures of the serological type Australis, demonstrated weak inhibition effect $-12.2 \%$.

The data, obtained during the experiments of studying the effect of $C$. proteus filtrates in $1: 10,000$ dilution on the cultures of serological groups of leptospires under investigation, demonstrated that there was no statistically reliable difference between the density of $L$. interrogans cells in the experiment and the control (Table 5). Therefore, at this concentration of BAS, secreted by green algae, in the aqueous medium, leptospires were not affected by the allelopathic impact from them.

\section{DISCUSSION}

The results of studies demonstrated that the pathogenic spirochetes of L. interrogans responded explicitly to the allelopathic effect of green algae C. proteus only under sufficiently high content of BAS, secreted by the latter during their existence, in the aqueous medium $(1: 10-1: 100)$. Similar conditions may occur in natural sources of leptospirosis, water bodies, during a warm season in the period of mass propagation of this type of algae, when the content of BAS, secreted by them, is the highest. As green algae C. proteus affect $L$. interrogans spirochetes via the change in characteristics of their existence medium, ecological interspecies relationships between them should be deemed topical. At the same type, it should be noted that leptospire cultures of serological types, used in the studies, demonstrated different sensitivity to the presence of similar concentrations of BAS from algae in the medium. Thus, according to the increasing sensitivity to the allelopathic effect of algae, the investigated serological types formed the following row: Tarassovi, Icterohaemorrhagiae, Pomona, Grippotyphosa, Australis, Sejroe, Canicola, Hebdomadis. The mechanisms, conditioning similar differences in the response to ecological factors of different serological groups of leptospires, are yet to be studied in the full detail. However, their adaptive significance was absolutely evident - a complicated intraspecies structure of $L$. interrogans determined wide ecological flexibility of this species, which allows it to exist in different environmental conditions and ensures the resistance to the effect of many ecological factors.

\section{CONCLUSIONS}

In the experiment, a topical type of ecological interspecies relationships is formed between L. interrogans and green species of $C$. proteus algae, which is realized through the release of biologically active substances into the habitat by $C$. proteus. Explicit inhibition of leptospire cultures under investigation was observed only in the samples with low dilutions of $1: 10-$ $1: 100$ algae filtrates. Pathogenic leptospires practically did not respond to the presence of BAS from algae in the medium under the filtrate dilution indices of 1 : $1,000-1: 10,000$. The serological types of leptospires, used in the experiment, demonstrated different sensitivity to the presence of BAS, secreted by C. proteus, 


\section{EXPERIMENTAL ECOLOGICAL RESEARCH ON THE RELATIONSHIPS}

in the medium which demonstrates considerable ecological plasticity of $L$. interrogans. The obtained results of investigations give grounds to consider freshwater algae as one of powerful biotic factors of affecting the existence of pathogenic leptospires in freshwater bodies. Relevant epidemic and epizootic significance of L. interrogans as a leptospirosis factor requires further subsequent studies.

This study was not financed by any specific grant from financing institutions in the state, commercial or noncommercial sectors.

There was no conflict of interests while conducting the investigations and publishing the results.

\section{Еколого-експериментальне дослідження взаємозв'язків патогенних мікроорганізмів з водоростями}

О. М. Жукорський ${ }^{1}$, Н. П. Ткачук ${ }^{2}$, О. В. Гулай ${ }^{3}$, В. В. Гулай ${ }^{3}$

${ }^{1}$ Національна академія аграрних наук України, 9, вул. Омеляновича-Павленка, 9, Київ, Україна, 01010

${ }^{2}$ Інститут агроекології і природокористування НААН України,

12, вул. Метрологічна, Київ, Україна, 03143

${ }^{3}$ Центральноукраїнський державний педагогічний університет

імені Володимира Винниченка,

1, вул. Шевченка, м. Кропивницький, Україна, 25006

e-mail: o_zhukorskiy@ukr.net,ol.gulay42@gmail.com*, tkachuknatalja777@gmail.com, vit.gulay@gmail.com

Мета. 3'ясувати в експерименті характер екологічних зв'язків між спірохетами Leptospira interrogans та водоростями Chlamydomonas proteus, а також виразність реакції окремих серологічних типів лептоспір на алелопатичний вплив водоростей. Методи. Монокультури водоростей $C$. proteus вирощували на середовищі Фітцджеральда в модифікації Цендера та Горема. Стерильні фільтрати їх культур розводили поживним середовищем у співвідношенні $1: 10,1: 100,1: 1000,1: 10000$. Лептоспір культивували на середовищі Терських та Кортгофа 3 додаванням 10 \% інактивованої сироватки крові овець. Дослідні зразки містили розведені культуральні фільтрати водоростей та лептоспір. Контрольні - середовище для культивування водоростей та лептоспір. Результати. У зразках із розведенням фільтратів водоростей $1: 10-1: 100$ вміст лептоспір у дослідних зразках був достовірно нижчим ніж у контролі, що свідчить про їх помірне та слабке пригнічення. У зразках із розведенням фільтратів водоростей $1: 1000-1: 10000$ статистично достовірної різниці між щільністю культур спірохет у досліді та контролі не було. Висновки. В експерименті між патогенними мікроорганізмами L. interrogans та зеленим видом во- доростей $C$. proteus формується топічний тип екологічних міжвидових зв'язків, що реалізується через виділення останнім у середовище існування біологічноактивних речовин. За зростанням чутливості до алелопатичного впливу C. proteus серологічні типи лептоспір утворили наступний ряд: Tarassovi, Icterohaemorrhagiae, Pomona, Grippotyphosa, Australis, Sejroe, Canicola, Hebdomadis.

Ключові слова: Leptospira interrogans, Chlamydomonas proteus, екологічні взаємозв'язки.

\section{Эколого-экспериментальное исследование взаимосвязей патогенных микроорганизмов и водорослей}

О. М. Жукорский ${ }^{1}$, Н. П. Ткачук ${ }^{2}$, О. В. Гулай ${ }^{3}$, В. В. Гулай ${ }^{3}$

${ }^{1}$ Национальная академия аграрных наук Украины, 9, ул. Омельяновича-Павленка, Киев, Украина, 01010

${ }^{2}$ Институт агроэкологии и природопользования НААН Украины,

12, ул. Метрологическая, Киев, Украина, 03143

${ }^{3}$ Центральноукраинский государственный педагогический университет имени Владимира Винниченка

1, ул. Шевченко, г. Кропивницкий, Украина, 25006

e-mail: o_zhukorskiy@ukr.net,ol.gulay42@gmail.com*, tkachuknatalja777@gmail.com,vit.gulay@gmail.com

Цель. Выяснить в эксперименте экологические связи между спирохетами Leptospira interrogans и водорослями Chlamydomonas proteus, а также выраженность реакции отдельных серологических типов лептоспир на аллелопатическое влияние водорослей. Методы. Монокультуры водорослей C. proteus выращивали на среде Фитцджеральда в модификации Цендера и Горема. Стерильные фильтраты их культур разводили питательной средой в соотношении $1: 10,1: 100,1: 1000$, $1: 10000$. Лептоспир культивировали на среде Терских и Кортгофа с добавлением $10 \%$ инактивированной сыроватки крови овец. Опытные образцы содержали разведенные культуральные фильтраты водорослей и лептоспир. Контрольные - среду для культивирования водорослей и лептоспир. Результаты. В образцах с разведением водорослей $1: 10-1: 100$ содержание лептоспир в опытных образцах было достоверно ниже, чем в контроле, что свидетельствует об их умеренном и слабом угнетении. В образцах с разведением фильтратов водорослей $1: 1000-1: 10000$ статистически достоверной разницы между плотностью культур спирохет в опыте и контроле не было. Выводы. В эксперименте между L. interrogans и водорослью C. proteus формируется топический тип экологических межвидовых связей, который реализуется через выделение последним в среду обитания биологически-активных веществ. За возрастанием чувствительности к аллело- 
патическому влиянию C. proteus серологические типы лептоспир образовывают ряд: Tarassovi, Icterohae-morrhagiae, Pomona, Grippotyphosa, Australis, Sejroe, Canicola, Hebdomadis.

Ключевые слова: Leptospira interrogans, Chlamydomonas proteus, экологические взаимосвязи.

\section{СПИСОК ЛІТЕРАТУРИ}

1. Vieira AS, D A Andrea PS, Vilela RdV, Loretto D, Jaeger LH, Carvalho-Costa FA, Lilenbaum W. Pathogenic Leptospira species are widely disseminated among small mammals in Atlantic Forest biome. Transboundary and Emerging Diseases. 2019;66(3):1195-201. doi: 10.1111/tbed.13135.

2. Rockwell KE, Thompson D, Maddox C, Mitchell MA. Blanding's turtles (Emydoidea blandingii) as a reservoir for Leptospira spp. PLoS One. 2019;14(6):e0210688. doi: 10.1371/journal.pone.0210688.

3. Xiao X, Zhou SH, Jiang N, Tian DZ, Zhou ZM, Zhang $M$, Ke H, Jiang XC, Lv WL, Gao QH. First record of Leptospira and Blastocystis infections in captive flying squirrels (Trogopterus xanthipes) from Enshi County, China. Acta Tropica. 2019;197:105065. doi: 10.1016/j. actatropica.2019.105065.

4. Marquez A, Ulivieri T, Benoit E, Kodjo A, Lattard V. House Mice as a Real Sanitary Threat of Human and Animal Leptospirosis: Proposal for Integrated Management. BioMed Res. Inter. 2019; 2019:ID 3794876. doi: 10.1155/ 2019/3794876.

5. Zhang C, Xu J, Zhang T, Qiu H, Li Z, Zhang E, Li S, Chang YF, Guo X, Jiang X, Zhu Y. Genetic characteristics of pathogenic Leptospira in wild small animals and livestock in Jiangxi Province, China, 2002-2015. PLoS Neglected Tropical Diseases. 2019;13(6):e0007513. doi: 10.1371/journal.pntd.0007513.

6. Kumar S, Lata KS, Sharma P, Bhairappanavar S, Soni $S$, Das $J$. Inferring pathogen-host interactions between Leptospira interrogans and Homo sapiens using network theory. Scientific Reports. 2019;9(1):1434. doi: 10.1038/ s41598-018-38329-1.

7. Hamond C, Silveira C, Buroni F, Suanes A, Nieves $C$, Salaberry X, Aráoz V, Costa RA, Rivero R, Giannitti $F$, Zarantonelli L. Leptospira interrogans serogroup Pomona serovar Kennewicki infection in two sheep flocks with acute leptospirosis in Uruguay. Transbound Emerg Dis. 2019;66(3):1186-94. doi: 10.1111/tbed.13133.

8. Neela VK, Azhari NN, Joseph N, Mimie NP, Ramli SNA, Mustapha NF, Ishak SN, Mohd-Taib FS, Yusof MA, Desa $M N$, Bashiru G, Sekawi Z. An outbreak of leptospirosis among reserve military recruits, Hulu Perdik, Malaysia. Eur. J. Clin. Microbiol. Infect. Dis. 2019;38(3):523-28. doi: 10.1007/s10096-018-03450-6.

9. Blasdell KR, Morand S, Perera D, Firth C. Association of rodent-borne Leptospira spp. with urban environments in Malaysian Borneo. PLoS Neglected Tropical Di-seases. 2019;13(2):e0007141. doi: 10.1371/journal.pntd.0007141.

10. Yatbantoong $N$, Chaiyarat $R$. Factors Associated with
Leptospirosis in Domestic Cattle in Salakphra Wildlife Sanctuary, Thailand. Int. J. Environ. Res. Public. Health. 2019;16(6):E1042. doi: 10.3390/ijerph16061042.

11. Rahelinirina S, Bourhy P, Andriamiaramanana F, Garin B, Rajerison M. High Prevalence of Leptospira spp. in Rodents in an Urban Setting in Madagascar. Am. J. Trop. Med. Hyg. 2019;100(5):1079-81. doi: 10.4269/ajtmh.18-0642.

12. Briskin EA, Casanovas-Massana A, Ryff KR, MoralesEstrada S, Hamond C, Perez-Rodriguez NM, Benavidez $K M$, Weinberger DM, Castro-Arellano I, Wunder EA, Sharp TM, Rivera-Garcia B, Ko AI. Seroprevalence, risk factors, and rodent reservoirs of leptospirosis in an urban community of Puerto Rico, 2015. J. Infect. Dis. 2019;220(9):1489-97. doi: 10.1093/infdis/jiz339.

13. Aziz MA, Aung MS, Paul SK, Ahmed S, Haque N, Roy S, Al Amin M, Paul A, Miah MA, Alam MK, Islam MS, Hossain MA, Kobayashi N. First molecular identification of two Leptospira species (Leptospira interrogans and Leptospira wolffii) in Bangladesh. New Microbes New Infect. 2019;31:100570. doi: 10.1016/j.nmni.2019.100570.

14. Fischer S, Mayer-Scholl A, Imholt C, Spierling NG, Heuser E, Schmidt S, Reil D, Rosenfeld UM, Jacob J, Nöckler K, Ulrich RG. Leptospira Genomospecies and Sequence Type Prevalence in Small Mammal Populations in Germany. Vector Borne Zoonotic Dis. 2018;18(4):18899. doi: 10.1089/vbz.2017.2140.

15. Dietrich M, Gomard Y, Lagadec E, Ramasindrazana B, Le Minter G, Guernier V, Benlali A, Rocamora G, Markotter W, Goodman SM, Dellagi K, Tortosa P. Biogeography of Leptospira in wild animal communities inhabiting the insular ecosystem of the western Indian Ocean islands and neighboring Africa. Emerg. Microbes. Infect. 2018;7(1):57. doi: 10.1038/s41426-018-0059-4.

16. McVea DA, Himsworth CG, Patrick DM, Lindsay LR, Kosoy M, Kerr T. Exposure to Rats and Rat-Associated Leptospira and Bartonella Species Among People Who Use Drugs in an Impoverished, Inner-City Neighborhood of Vancouver, Canada. Vector Borne Zoonotic Dis. 2018;18(2):82-8. doi: 10.1089/vbz.2017.2179.

17. Casanovas-Massana A, Pedra GG, Wunder EA, Jr, Diggle PJ, Begon M, Ko AI. Quantification of Leptospira interrogans Survival in Soil and Water Microcosms. Appl Environ Microbiol. 2018;84(13):e00507-18. doi: 10.1128/AEM.00507-18.

18. Stone S, Adams MS, Stauber JL, Jolley DF, Warne MSJ. Development and application of a multispecies toxicity test with tropical freshwater microalgae. Environ Pollut. 2019;250:97-106. doi: 10.1016/j.envpol.2019.03.058.

19. Pat. No. 94462 Ukraine. MPK G01N 33/48 (2006/01). Method of evaluating the impact of ecological factors on populations (cultures) of microorganisms. O.V. Hulai, O.M. Zhukorskyi, V.I. Hulai, V.V. Hulai, N.P. Tkachuk; applicant and patent owner O.V. Hulai, O.M. Zhukorskyi, V.I. Hulai, V.V. Hulai, N.P. Tkachuk. No. u2014 06645; appl. 13/06/14; publish. 10/11/14. Bull. No. 21. 4p. 